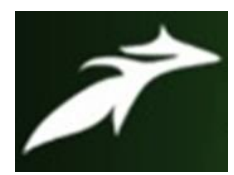

Ashish Shah et al, International Journal of Advances in Agricultural Science and Technology,

Vol.8 Issue.1, January-2021, pg. 90-98

ISSN: 2348-1358

Impact Factor: 6.057

NAAS Rating: 3.77

\title{
ADOPTION BEHAVIOR OF GOND FARMERS ABOUT IMPROVED FARMING PRACTICES OF SUGARCANE IN LUNDRA BLOCK OF SURGUJA DISTRICT IN CHHATTISGARH
}

\author{
Ashish Shah'; Dr. Jahanara ${ }^{2}$ \\ M.Sc. Scholar, Head of the Department \\ Department of Agricultural Extension \& Communication \\ Sam Higginbottom University of Agricultural Technology \& Sciences, Prayagraj (211007) \\ Research Scholar* E-mail: ashishshah1095671@ @mail.com \\ Professor** E-mail: jajahanr648@gmail.com \\ DOI: 10.47856/ijaast.2021.v08i1.012
}

\begin{abstract}
The present study was conducted in the Surguja district of Chhattisgarh. From the present study it was undertaken to find out the adoption level of gond farmers towards sugarcane farming practices was conducted in lundra block of sarguja district. The 120 respondents were selected from 10 villages of sarguja district by proportionate random sampling method. The data were collected by personal interview method with the help of pre-structured interview schedule. The study revealed that majority of the respondents had medium level of socio-economic status found that majority of respondents i.e. 57.50 per cent of the total respondents were in the medium level of adoption group, whereas 14.17 per cent respondents were in low adoption group and remaining 28.33 per cent sugarcane growers were observed in the category of high level of adoption about sugarcane production technology. There was positively and non-significant relationship between age, education, family type, family size and significant relationship with annual income and land holding.
\end{abstract}

Keywords: Adoption, Sugarcane farming practices, Socio-economic profile

\section{INTRODUCTION}

Agriculture is the predominant sector of Indian economy that meets the basic requirements such as food, clothing and shelter of the people, which contributes nearly 17.9 per cent to the national income (Ministry of Statistics and Programme Implementation, Planning commission, Government of India 2011). It is indigenous to the warm temperate to tropical climates of South and Southeast Asia, although it is now grown in more than 100 different countries around the world (FAO, 2019). The role of agriculture in the economy of India may be considered in the light of contribution it makes in three important aspects i.e., national income, employment generation and foreign exchange. India has a wide diversity of crops, among them food grains occupy a major portion of the land area, while sugarcane and fibre crops occupy relatively lesser acreage (Goldemberg et al, 2007). 


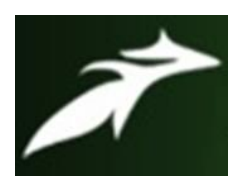

Ashish Shah et al, International Journal of Advances in Agricultural Science and Technology, Vol.8 Issue.1, January-2021, pg. 90-98

ISSN: 2348-1358

Impact Factor: 6.057

NAAS Rating: 3.77

Sugarcane (Saccharum officinarum L.) is an important commercial crop of India. Sugarcane and sugar beet are used for large scale production of sugar in the world. Amongst the sugar producing plants, sugarcane is responsible for about 60.00 per cent of world's sugar production (Swinnen and Squicciarini, 2012; Sexton and Zilberman, 2008). Sugarcane is cultivated mainly in the tropics, though in India it is also grown in sub-tropical areas. Sugarcane is the main source of sugar in Asia and Europe. Sugarcane is grown primarily in the tropical and sub-tropical zones of the southern hemisphere. Sugarcane is the raw material for the production of white sugar, jaggery (gur) and khandsari. It is also used for chewing and extraction of juice for beverage purpose. Sugarcane is becoming an important cash crop for farmers because there is a great potential for sugar production and by products of sugarcane in domestic market. This may be one of the reasons for poor average sugarcane yield and sugar recovery as compared to both potentiality of sugarcane yield and recovery. Sugarcane and sugar output can be increased if the growers adopt the recommended package relating to sugarcane production technology (De Andrade et al., 2011; Silva et al., 2010). For increasing the level of adoption, farmers need to be convinced about recent knowledge regarding production technologies. In this regard, it is imperative to examine their status of knowledge and the factors which hinder the process of their adoption.

\section{RESEARCH METHODOLOGY:}

The present study was conducted in Sarguja district of Chattisgarh state which is purposively selected based on research objective and criteria of sampling concerning adoption behaviour of gond farmers towards sugarcane farming practices. In Lundra block of Sarguja district, 10 villages were selected randomly for the present study. Total 120 number of respondents were selected from each selected village for the present study. The primary data was collected with the help of pre-tested- structured interview schedule, designed especially in the light of objectives, whereas secondary data was collected from sources like thesis, journals, literature etc. Percentage analysis were done to analyse the data. And ranking was done according to results obtained.

Data collected were qualitative as well as quantitative. Qualitative data were converted into quantitative data. The quantitative data were tabulated on the basis of logical categorization method. Percentage, Coefficient correlation and Microsoft Excel were used for analysis purpose.

\section{RESULTS AND DISCUSSION}

\section{Distribution of Socio-economic Profile Of the respondents}

Table-1: Distribution of the respondents according to their Age.

\begin{tabular}{|l|l|l|l|}
\hline $\begin{array}{l}\text { S.I. } \\
\text { No. }\end{array}$ & \multicolumn{1}{|c|}{ Age (years) } & Frequency & Percentage \\
\hline 1 & Young (Below 38 years) & 38 & 31.66 \\
\hline 2 & Middle age (38-53) & 56 & 46.67 \\
\hline 3 & Old (above 53) & 26 & 21.66 \\
\hline & Total & 120 & 100 \\
\hline
\end{tabular}




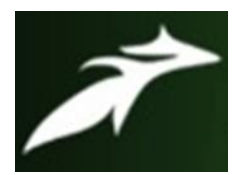

Ashish Shah et al, International Journal of Advances in Agricultural Science and Technology, Vol.8 Issue.1, January-2021, pg. 90-98

ISSN: 2348-1358

Impact Factor: 6.057

NAAS Rating: 3.77

The data in the above table showed that most of the respondents 46.67 per cent have middle aged group followed by 31.67 per cent of respondents belonged to young aged group and 13.33 per cent felled in old age group.

From the above analysis, it may be concluded that majority of the farmer in the study area belonged to middle age group Bhabhor et al. (2017) \& Ahire et al. (2018) also noted almost similar.

Table-2: Distribution of the respondents according to their Education.

\begin{tabular}{|l|l|l|l|}
\hline $\begin{array}{l}\text { SI } \\
\text { no. }\end{array}$ & Particulates & Frequency & Percentage \\
\hline 1 & Illiterate & 20 & 16.66 \\
\hline 2 & Primary & 52 & 43.34 \\
\hline 3 & High school \& above & 48 & 40.00 \\
\hline & Total & 120 & 100 \\
\hline
\end{tabular}

The data in the above table showed that most of the respondents 43.34 per cent have primary educational level followed by 40.00 per cent of respondents belonged to high school \& above level and 16.66 per cent felled in illiterate category.

From the above analysis, it may be concluded that majority of the farmer in the study area belonged to primary category educational status Marradi (2006) \& Ahire et al. (2018) also noted almost similar.

Table-3: Distribution of the respondents according to size of land holding.

\begin{tabular}{|l|l|l|l|}
\hline $\begin{array}{l}\text { SI } \\
\text { no. }\end{array}$ & Particulates & Frequency & Percentage \\
\hline 1 & Low (up to 3 bighas) & 38 & 31.66 \\
\hline 2 & Medium (3 to 6 bighas) & 45 & 37.50 \\
\hline 3 & High (above 6 bighas) & 37 & 30.84 \\
\hline & Total & 120 & 100 \\
\hline
\end{tabular}

The data in the above table showed that most of the respondents 37.50 per cent have medium level land holding followed by 31.66 per cent of respondents belonged to low level land holding and 30.84 per cent felled in high category land holding.

From the above analysis, it may be concluded that majority of the farmer in the study area belonged to medium size land holding Mande (2009) also noted almost similar. 


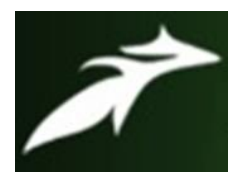

Ashish Shah et al, International Journal of Advances in Agricultural Science and Technology, Vol.8 Issue.1, January-2021, pg. 90-98

ISSN: 2348-1358

Impact Factor: 6.057

NAAS Rating: 3.77

Table -4: Distribution of the respondents according to their Annual income.

\begin{tabular}{|l|l|l|l|}
\hline $\begin{array}{l}\text { SI } \\
\text { no. }\end{array}$ & Particulates & Frequency & Percentage \\
\hline 1 & Low (Up to Rs. 40000) & 40 & 33.33 \\
\hline 2 & Medium (Rs.40000-80000) & 51 & 42.50 \\
\hline 3 & High (more than Rs.80000) & 29 & 24.17 \\
\hline & Total & 120 & 100 \\
\hline
\end{tabular}

It is clear from the above table that 42.50 per cent respondents have Annual income betweenRs.40000-80000, 33.33 per cent respondents have up to Rs.40000, and 24.17 per cent respondents have income more than Rs.80000.

From the above analysis, it may be concluded that majority of the farmer in the study area belonged to medium size land holding Bhabhor et al. (2017) \& Godara et al. (2020) also noted almost similar.

Table-5: Distribution of the respondents according to their family size.

\begin{tabular}{|l|l|l|l|}
\hline $\begin{array}{l}\text { SI } \\
\text { no. }\end{array}$ & Particulates & Frequency & Percentage \\
\hline 1 & Small (up to 5 members) & 36 & 30.00 \\
\hline 2 & Large (above 5 members) & 84 & 70.00 \\
\hline & Total & 120 & 100 \\
\hline
\end{tabular}

The above table shows that 70.00 per cent respondents have large size and other 30.00 per cent respondents have small size.

From the above analysis, it may be concluded that majority of the farmer in the study area belonged to large sized family type Bhabhor $\boldsymbol{e t}$ al. (2017) also noted almost similar.

Table-6: Distribution of the respondents according to their family types.

\begin{tabular}{|l|l|l|l|}
\hline $\begin{array}{l}\text { SI } \\
\text { no. }\end{array}$ & Particulates & Frequency & Percentage \\
\hline 1 & Nuclear families & 44 & 36.67 \\
\hline 2 & Joint families & 76 & 63.33 \\
\hline & Total & 120 & 100 \\
\hline
\end{tabular}

The above table shows that 63.33 per cent respondents have joint families and other 36.67 per cent respondents have nuclear families.

From the above analysis, it may be concluded that majority of the farmer in the study area belonged to joint families type Ahire et al. (2018) also noted almost similar. 


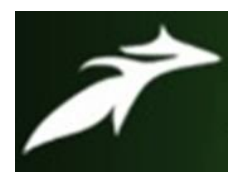

Ashish Shah et al, International Journal of Advances in Agricultural Science and Technology, Vol.8 Issue.1, January-2021, pg. 90-98

ISSN: 2348-1358

Impact Factor: 6.057

NAAS Rating: 3.77

Table-7. Distribution of respondents according to their source of Information.

\begin{tabular}{|l|l|l|l|l|}
\hline Sl. No. & Particulars & Frequently & Occasionally & Rarely \\
\cline { 3 - 5 } & & F (\%) & F (\%) & F (\%) \\
\hline 1. & Radio & $35(29.16)$ & $69(57.50)$ & $16(13.33)$ \\
\hline 2. & Television & $44(36.67)$ & $53(44.17)$ & $23(19.16)$ \\
\hline 3. & Newspaper & $36(30)$ & $52(43.33)$ & $32(26.67)$ \\
\hline 4. & Mobile & $35(29.17)$ & $52(43.33)$ & $33(27.50)$ \\
\hline 5. & Computer & $05(4.16)$ & $48(40)$ & $67(55.84)$ \\
\hline 6. & Internet & $52(43.34)$ & $54(45)$ & $14(11.66)$ \\
\hline 7. & Extension person & $28(23.34)$ & $69(57.5)$ & $23(19.16)$ \\
\hline 8. & NGO & $23(19.17)$ & $65(54.17)$ & $32(26.66)$ \\
\hline 9. & Any other & $13(10.83)$ & $69(57.50)$ & $38(31.66)$ \\
\hline
\end{tabular}

\begin{tabular}{|l|c|c|c|}
\hline \multirow{2}{*}{ S. } & Category & \multicolumn{2}{|c|}{ Respondents (120) } \\
\cline { 2 - 4 } & & Frequency & Percentage \\
\hline 1 & Low (9-14) & 37 & 30.83 \\
\hline 2 & Medium (15-21) & 59 & 49.67 \\
\hline 3 & High (22-27) & 24 & 24.00 \\
\hline & Total & $\mathbf{1 2 0}$ & $\mathbf{1 0 0}$ \\
\hline
\end{tabular}

The above table shows that majority $(49.67 \%)$ of the organic respondents had medium level of information seeking behaviour in organic vegetable cultivation. Followed by low 30.83 per cent had low and 24.00 percent had high information seeking behaviour respectively. 


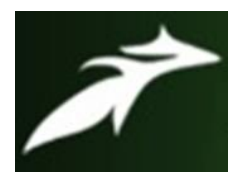

Ashish Shah et al, International Journal of Advances in Agricultural Science and Technology, Vol.8 Issue.1, January-2021, pg. 90-98

ISSN: 2348-1358

Impact Factor: 6.057

NAAS Rating: 3.77

Table-8. Distribution of respondents according to their Extension contact.

\begin{tabular}{|l|l|l|l|l|}
\hline \multirow{2}{*}{ S. No. } & \multirow{2}{*}{$\begin{array}{l}\text { Extension } \\
\text { Personnel }\end{array}$} & \multicolumn{3}{|c|}{ Contact } \\
\cline { 3 - 5 } & & Regular & Occasional & Never \\
\cline { 3 - 5 } & & F (\%) & F (\%) & F (\%) \\
\hline 1. & VDO/BDO & $22(18.33)$ & $62(51.67)$ & $36(30)$ \\
\hline 2. & ADO & $25(20.84)$ & $53(44.16)$ & $42(35)$ \\
\hline 3. & SMS & $18(15)$ & $49(40.83)$ & $53(44.17)$ \\
\hline 4. & NGO & $20(16.67)$ & $43(35.83)$ & $57(47.5)$ \\
\hline $\mathbf{5 .}$ & Any other & $15(12.5)$ & $58(48.33)$ & $47(39.17)$ \\
\hline
\end{tabular}

\begin{tabular}{|l|c|l|l|}
\hline \multirow{2}{*}{ S. } & Category & \multicolumn{2}{|c|}{ Respondents (120) } \\
\cline { 3 - 4 } & & Frequency & Percentage \\
\hline 1 & Low (5-8) & 44 & 36.66 \\
\hline 2 & Medium (9-12) & 53 & 44.67 \\
\hline 3 & High (13-15) & 23 & 19.17 \\
\hline & Total & $\mathbf{1 0 0}$ & $\mathbf{1 0 0}$ \\
\hline
\end{tabular}

The above Table- 8 , shows that out of the total respondents, most of the respondents 44.67 per cent were found to medium extension contact followed by low extension contact category 36.66 per cent and high extension contact category 19.17 per cent respectively. 


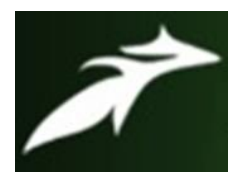

Ashish Shah et al, International Journal of Advances in Agricultural Science and Technology, Vol.8 Issue.1, January-2021, pg. 90-98

ISSN: 2348-1358

Impact Factor: 6.057

NAAS Rating: 3.77

\section{ADOPTION LEVEL OF GOND FARMERS TOWARDS ORGANIC SUGARCANE FARMING PRACTICES}

Table-9: Distribution of the respondents according to their Adoption level.

\begin{tabular}{|c|c|c|c|c|}
\hline \multirow[t]{2}{*}{ S. No. } & \multirow[t]{2}{*}{ Aspects/ Practices } & \multicolumn{3}{|c|}{$\begin{array}{l}\text { Adoption } \\
\text { Level }\end{array}$} \\
\hline & & $\begin{array}{c}\text { Fully } \\
\text { Adopted } \\
\text { F (\%) }\end{array}$ & $\begin{array}{l}\text { Partially } \\
\text { Adopted } \\
\text { F }(\%)\end{array}$ & $\begin{array}{c}\text { Not } \\
\text { Adopted } \\
\text { F (\%) }\end{array}$ \\
\hline 1. & Use of high yielding varieties & $\begin{array}{l}30 \\
(25.00)\end{array}$ & $\begin{array}{l}70 \\
(58.33)\end{array}$ & $\begin{array}{l}20 \\
(16.66)\end{array}$ \\
\hline 2. & Soil and field preparation & $\begin{array}{l}40 \\
(33.33)\end{array}$ & $\begin{array}{l}65 \\
(54.16)\end{array}$ & $\begin{array}{l}15 \\
(12.50)\end{array}$ \\
\hline 3. & Soil treatment & $\begin{array}{l}35 \\
(29.16)\end{array}$ & $\begin{array}{l}70 \\
(58.33)\end{array}$ & $\begin{array}{l}15 \\
(12.50)\end{array}$ \\
\hline 4. & Seed treatment & $\begin{array}{l}38 \\
(31.67)\end{array}$ & $\begin{array}{l}62 \\
(51.66)\end{array}$ & $\begin{array}{l}20 \\
(16.67)\end{array}$ \\
\hline 5. & Time of sowing & $\begin{array}{l}55 \\
(45.83)\end{array}$ & $\begin{array}{l}50 \\
(41.66)\end{array}$ & $\begin{array}{l}15 \\
(12.50)\end{array}$ \\
\hline 6. & $\begin{array}{l}\text { Seed rate \& recommended } \\
\text { method of sowing }\end{array}$ & $\begin{array}{l}30 \\
(25.00)\end{array}$ & $\begin{array}{l}60 \\
(50.00)\end{array}$ & $\begin{array}{l}30 \\
(25.00)\end{array}$ \\
\hline 7. & Fertilizer application & $\begin{array}{l}30 \\
(25.00)\end{array}$ & $\begin{array}{l}65 \\
(54.16)\end{array}$ & $\begin{array}{l}25 \\
(20.84)\end{array}$ \\
\hline 8. & Irrigation management & $\begin{array}{l}40 \\
(33.33)\end{array}$ & $\begin{array}{l}60 \\
(50.00)\end{array}$ & $\begin{array}{l}20 \\
(16.67)\end{array}$ \\
\hline 9. & Weed management & $\begin{array}{l}27 \\
(22.50)\end{array}$ & $\begin{array}{l}63 \\
(52.50)\end{array}$ & $\begin{array}{l}30 \\
(25.00)\end{array}$ \\
\hline 10. & Plant protection measures & $\begin{array}{l}32 \\
(26.66)\end{array}$ & $\begin{array}{l}68 \\
(56.66)\end{array}$ & $\begin{array}{l}20 \\
(16.67)\end{array}$ \\
\hline 11. & Harvesting & $\begin{array}{l}45 \\
(37.50)\end{array}$ & $\begin{array}{l}60 \\
(50.00)\end{array}$ & $\begin{array}{l}15 \\
(12.50)\end{array}$ \\
\hline
\end{tabular}




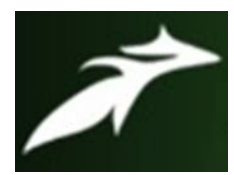

Ashish Shah et al, International Journal of Advances in Agricultural Science and Technology, Vol.8 Issue.1, January-2021, pg. 90-98

ISSN: 2348-1358

Impact Factor: 6.057

NAAS Rating: 3.77

Table -9.1: Distribution of respondents on the basis of their adoption level

\begin{tabular}{|l|c|c|c|}
\hline Adoption level & Knowledge score & Frequency & Total percent \\
\hline Low & Below 15 & 16 & 13.33 \\
\hline Medium & 15 to 19 & 72 & 60.00 \\
\hline High & Above 19 & 32 & 26.67 \\
\hline Total & & $\mathbf{1 2 0}$ & $\mathbf{1 0 0 . 0 0}$ \\
\hline
\end{tabular}

The data in the above table showed that most of the respondents 50.00 per cent have medium adoption level followed by 27.50 per cent of respondents belonged to low Adoption level and 22.50 per cent fell in high adoption level.

From the above analysis, it may be concluded that majority of the farmer in the study area belonged to medium adoption level in sugarcane farming by gond farmers Rathod et al. (2018) \& godara et al. (2020) also noted almost similar.

Table-10: Relationship between selected variables of sugarcane growers and their level of adoption of recommended package of practices

\begin{tabular}{|l|l|c|}
\hline S.No. & Independent variables & Correlation coefficient (r) \\
\hline 1. & Age & $0.085 \mathrm{NS}$ \\
\hline 2. & Education & $0.047 \mathrm{NS}$ \\
\hline 3. & Annual income & $0.258^{* *}$ \\
\hline 4. & Land holding & $0.515^{* *}$ \\
\hline 5. & Family size & $0.022 \mathrm{NS}$ \\
\hline 6. & Family type & $0.016 \mathrm{NS}$ \\
\hline 7. & Source of information & $0.361 * *$ \\
\hline 8. & Extension contacts & $0.247 * *$ \\
\hline
\end{tabular}

** Correlation is significant at the 0.05 level of probability NS= Non-significant 


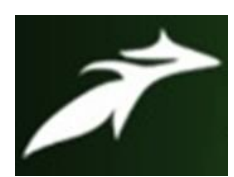

Ashish Shah et al, International Journal of Advances in Agricultural Science and Technology, Vol.8 Issue.1, January-2021, pg. 90-98

ISSN: 2348-1358

Impact Factor: 6.057

NAAS Rating: 3.77

There was positively and non-significant relationship between age, education, family type, family size and Cosmopolitan outlook and their level of adoption of recommended package of practices. The socio-economic characteristics namely annual income, land holding, source of information and extension contact were found to positively but non-significant related to extent of adoption of the respondents respectively.

Hence the null hypotheses H01.3, H01.4, H01.8\& H01.9 were rejected and alternate hypotheses were accepted. It means that age, education, family type, family size and Cosmopolitan outlook did not have a significant effect on the level of adoption of recommended package of practices.

\section{CONCLUSION}

It has been concluded that most of the respondents $(60.00 \%)$ had medium level of adoption followed by high (26.67\%) and low (13.33\%) and the relationship between adoption level and socio-economic profile of respondents shows that Annual income $\left(0.258^{*}\right)$, Land holding $(0.515 *)$, source of information and extension contacts were positively significant at $0.05 \%$ whereas age (0.085 NS), Education (0.047 NS), Family size (0.022NS), Family type(0.016NS) are positive but non-significant at $0.05 \%$ to extend of adoption of the respondent respectively. Hence it is imperative that government and to experts should take more steps like training, field demonstration, more interaction with farmers, more government schemes, loans so that more people can adopt sugarcane farming practices as it also generate lots of employments which will help in upliftment of farming society.

\section{References}

[1]. Ahire R. D. Kapase P. S. Deshmukh P.R. 2018 Knowledge and adoption of integrated pest management practices for cotton ISSN:23197706 vol.07 no.09

[2]. Bhabhor G. K. U.M. Patel and N. D. Makwana 2017. Factors affecting the technological gap of tribal wheat growers. KVK, AAU, Dahod Gujarat.

[3]. Godara, A., Kumar, V., Ghoslya A.K. and Kumar J., 2020. Knowledge of Farmers about Production Technology of Sugarcane in Sri Ganganagar District of Rajasthan, India, Int.J.Curr.Microbiol.App.Sci, 9(4): 245-248.

[4]. Mande, J.V and Thombre, B.M 2009. Adoption of cultivation practices by sugarcane growers. Ind. J.Extn.Edu.29(3): 178-181.

[5]. Marradi G. N. 2006.An analysis of sustainable cultivation practices followed by sugarcane growers in Karnataka state, P.hd. Thesis Univ. of Agril. Sci., Dharwad (India).

[6]. Rathod, G.V.; Salame, S.P.; and Deokate, N. (2018). Knowledge and adoption of improved cultivation practices by sugarcane growers. International Journal of Chemical Studies. 6(6): 653-654.

[7]. Singh (2018), Assessment of variations in yield gap and constraints analysis in the sugarcane production in Bihar. International Journal of Current Microbiology and Applied Sciences 6(7):2667-2675. 